\title{
THE STRUCTURE AND MEANING OF KAWIH IN RONGGENG GUNUNG PERFORMANCE
}

\author{
Dian Nurrachman, Rohanda, Hasbi Assiddiqi, Deden Hidayat \\ UIN Sunan Gunung Djati Bandung \\ diannurrachman@uinsgd.ac.id, rohanda@uinsgd.ac.id, hasbi.assiddiqi@uinsgd.ac.id, \\ deden.hidayat@uinsgd.ac.id
}

\begin{abstract}
Ronggeng Gunung is a combined performing art which thrives especially in southern Ciamis (including Pamarican and Banjarsari) and Pangandaran (including Padaherang and Kalipucang). Generally, this is almost the same as the conventional ronggeng, in which a dancer performs while being accompanied by gamelan (Javanese/Sundanese music instrument) and kawih (Sundanese songs). The main ronggeng dancer is a woman who wears a shawl as a part of the dance to invite males to dance with her. Allegedly, in its mythological narratives, Ronggeng Gunung was created from the grief of a princess who lost her beloved husband and her attempt of revenge toward the killer. This paper is actually intended to find out how are the structures and meanings of Kawih as an inseparable part of Ronggeng Gunung performance. This study applies structuralism as both theoretical approach and method, since it provides the theoretical framework to find out both the structural construction and the meaning of the Kawih. The result of this study shows that kawih accompanying Ronggeng Gunung performance represents a passionate romance of solace, unrequited love, as well as the cultural values of modesty, politeness, and the importance of solidarity in facing every problem encountered by human.
\end{abstract}

Keywords: Ronggeng Gunung, Structure, Meaning, Kawih.

\section{INTRODUCTION}

The anthropological study of literature is a new prospect for literary studies. This kind of study which attempts to combine two disciplines appears to be seldom sought after, when in fact there are many interesting things that can be explored. Through this model, literary researchers can reveal various anthropological hints. Researchers can also conduct the interdisciplinary study without restrictions because both literature and anthropology concern humanities. This type of study is necessary, but it does not mean literary study is covetous. There are many instances in literary work which contain ethnographical aspects of human life, and vice versa, ethnographic works containing literary metaphors are not 
little. Therefore, anthropological research of literature counts heavily on two things: (a) to study ethnographic writings related to literature in order to observe the aesthetics and (b) to study literary works from ethnographic perspective in order to find out the cultural aspects of the society (Endraswara, 2008, p. 107). This study then deal with the anthropology of literature in terms of the second, and therefore it requires an archetypal object, namely, the emphasis on the cultural heritage from the past as the object of the study (Endraswara, 2013, p. 60). The archetypal object itself arises from the idea that literature and arts are not only part of modern culture, but are also known and possessed by undeveloped society, which are still living within traditional culture (Semi, 199, p. 90).

Since this paper is a kind of anthropological study of literature, then, this study is started from the interesting facts that nowadays the local wisdom is undeniably marginalized by some external cultures that bring harms to the advancement of Indonesian national character. On this reason, this study investigates the comprehensive potentials in one of West Java's rich culture. West Java as one of the regions in Indonesia with Sundanese ethnic has quite a variety of regional art treasures, and some of them are included in the category of elitist art, although in its development thereafter it experiences a sharp shift towards popular art. The diversity and richness of Sundanese art are contextually manifested in the combination of arts tradition; from theatrical movements, dances, music, literature (mythology, narratives and poems that are often sung), to the symbolic elements of clothing and the colors of clothes worn in an art performance. Those construct not only the artistic value but also aesthetics and even character values, ethics, and others. This shows that the treasures of Sundanese art as a combined performing art are manifested on the basis of socio-cultural values that are collective, such as mutual cooperation and togetherness, harmony, respect for gender, and others.

Among the many performing arts in the region/province of West Java, Ronggeng Gunung is a performance art that is categorized as a combination art. Ronggeng Gunung is a combined performing art which thrives especially in Southern Ciamis (including Pamarican and Banjarsari) and Pangandaran (including Padaherang and Kalipucang). Generally, this is almost the same as the conventional ronggeng, in which a dancer performs while being accompanied by gamelan (Javanese/Sundanese music instrument) and kawih (Sundanese songs). The main ronggeng dancer is a woman who wears a shawl as a part of the dance. The shawl is used to invite males to dance with the dancer. The characteristic of Ronggeng Gunung is the sanctity and elitism founded in its creation. Allegedly, in its mythological narratives, Ronggeng Gunung was created from the grief of a princess namely Dewi Siti Samboja (Dewi Rengganis) who lost her beloved husband (Raden Anggalarang) and her attempt of revenge toward the killer. Thus, Ronggeng Gunung performance-especially the content of the narratives within the Kawih-can be categorized as myth. A study toward certain myths in a society has an important role to understand better how an event or a story about an event from the past is linked with a series of activities from the present, such as rites, farming procedure, education system, and artistic activities in the context of beliefs. 
The word myth is derived from the Greek word muthos, which literally means a story, or something told by someone; or in a broader definition, a statement, a narration, or a drama plot (Dhavamony, 1995, p. 147). Within the structural anthropological study, myths are understood as a story of a higher and more important truth about the reality of origination, which provides guidance and direction toward a certain group of people (Dhavamony, 1995, p. 147).

A myth is not only narrated in a story, but can also be expressed through dances. The cores of a story are symbols that can represent human experience: symbols of good and evil, life and death, sin and purification, marriage and fertility, blessing and protection of nature by spirits, etc. Myths give direction for human behavior and become guidance for human wisdom. Through myths, mankind can participate in the occurrences around them as a response toward natural powers (van Peursen, 1988, p. 12). Myths narrated from generation to generation will become an integral part of the paradigm and behavior pattern which in turn will guide mankind to understand myths as a part of historical consciousness. Here lies the problem which we raise in this section; that mythic consciousness is actually not far different from historical consciousness. The root of historical truth is basically a belief toward an event considered as true or factual. However, the truthfulness and the factuality of a historical event is always an interpretation of the event, and this is related with the human psychological aspect which includes the conscious realm and the unconscious realm. This is what Levi-Strauss (1955, p. 431) refers that the meaning of a myth lies in the combination and the interweaving between the constituents and it becomes a part of human consciousness. Therefore, a myth develops into a historical truth because the myth undergone a psychological internalization process within mankind which interprets a mythic event as true and had happened in the past.

Within this context, we observe that there is a similarity between how the interweaving of mythological narratives about the origin and foundation of ronggeng, specifically Ronggeng Gunung or mountain area ronggeng, which is delivered from one generation to another and the mythical aspects of the Kawih might become historical consciousness which is considered as a historical truth. Similar to how historical events have different types, versions, and interpretations, the myth of Ronggeng Gunung also has different versions. However, this paper is intended to provide neither the various versions of the myth nor the analytical study towards those various myths, or the analytical study of the whole Ronggeng Gunung performance. By finding out the answer for the question of how are the structures and meanings of Kawih as an inseparable part of Ronggeng Gunung performance, this study intended to provide the analytical discussion on Kawih as a literary genre which accompanies such a performance.

\section{THEORETICAL FRAMEWORK}


In every Ronggeng Gunung performance and also Ronggeng Kaler ${ }^{1}$, the dancers or the ronggeng are not only accompanied by music, but also accompanied by the melodious Kawih (Sundanese songs) sung by a pasindhén (traditional folk singer). There is a unique difference between the two performances, and it is related to the pasindhén and the ronggeng. In Ronggeng Gunung, pasindhén also plays the role of the ronggeng, so an extra energy is needed for the pasindhén since she has to show off her singing and dancing skill at the same time. However, in Ronggeng Kaler, the dancer and the singer are usually played by different individuals; pasindhén only sings and the ronggeng only dances. Another difference lies in the Kawih. The Kawih lyrics sung by Ronggeng Gunung are different from the one sung in Ronggeng Kaler. The lyrics of Ronggeng Kaler are far more modern than the lyrics of Ronggeng Gunung. Kawih in Ronggeng Kaler, according to Ma Ita², is usually sung by young people because it is a popular entertainment, so the Kawih also has to be popular, and that the songwriter can be traced. Meanwhile, Kawih sung in Ronggeng Gunung, according to Bi Raspi ${ }^{3}$, does not have a certain songwriter and has existed in the society as if it was born out of nowhere. The lyrics in Ronggeng Gunung are a process of oral tradition passed down from one generation to another generation, so the original songwriter is hard to be traced. This kind of tradition is a typical tradition in folklore study. Therefore, if the lyrics of Ronggeng Gunung performance are listened to the people of West Java, especially the ones coming from Ciamis and Pangandaran, who speak Sundanese, they will easily understand the content of the lyrics, because the lyrics are derived from sisindiran (Sundanese poems) tradition which has already been engraved in the Sundanese society.

Based on the context, Sundanese poem called sisindiran is a type of Sundanese poem which is similar to pantun (four-line poem with ABAB rhymes) in Malayan poem. Sisindiran, according to Salmun (1968, p. 64) $)^{4}$, is a word processing art formed by cangkang (shell) and followed by eusi (content), which is used to utter something figuratively and not directly. Furthermore, Salmun explains that there are three types of sisindiran, namely: wawangsalan, rarakitan, and paparikan. Wawangsalan is also known as bangbalikan because the word wawangsalan itself is derived from the word wangsul which means to come back or turn. It is a type of sisindiran consisted of a verse of cangkang and a verse of eusi. Wawangsalan is actually a word processing in the form of riddles which each has a certain intention. Wawangsalan is often used in daily conversations, therefore even if only the cangkang is said, people will understand the continuation of the verses and the intention of the speaker. Therefore, when someone says "teu puguh monyet hideungna," usually the

\footnotetext{
${ }^{1}$ The term ronggeng kaler was originated from the southern part of Ciamis, in which because of the division of regencies, it is now part of Pangandaran. However, there is another term to call this performing art beside ronggeng gunung, namely ronggeng kidul and ronggeng amen. It is called as ronggeng kidul because its origin is from the northern part of Ciamis/Pangandaran, meanwhile the word 'amen' is derived from the word 'ngamen' (busking), because the performance is indeed expecting saweran (money thrown by the audiences), where in practice the audiences will fold the money into the end of the shawl worn by the pasindhén.

${ }^{2}$ Interview was conducted on August 15, 2017

${ }^{3}$ Interview was conducted on October 6, 2017

${ }^{4}$ M.A. Salamun, Kandaga: Kasusatran. Gunaco. Bandung: 1968.
} 
listeners will know that the continuation is "teu puguh tungtungna." Literally, "teu puguh monyet hideungna" means it's unclear the blackness of a monkey, and the verse "teu puguh tungtungna," means that the end is unclear. Therefore, the meaning of the wawangsalan is an unclear agreement or end. Moreover, wawangsalan at the same time is also a riddle about the lutung. The hints about the answer lie on the words 'monyet hideung' and 'tungtung', therefore a black monkey which ends with"-tung" is a lutung.

The second type of sisindiran is rarakitan, which is sisindiran consisted of two cangkang and two eusi. This kind of sisindiran is called rarakitan because it consists of two pairing verses, which in Sundanese is called as sarakit ${ }^{5}$, or a pair. To be clearer, see an example of rarakitan below:

From the example above, we can observe that the first verse and the second verse are in

Sapanjang jalan Soréang,

moal weléh diaspalan.

Sapanjang tacan kasorang,

moal weléh diakalan. ${ }^{6}$
Along the road of Soreang

must always be covered in asphalt

As long as it's not achieved yet

must always give effort

pair with the third and fourth verses. So, the first two verses are in pair with the last two verses; this pair is known as sarakit or in pair. Because of this pairing pattern, this sisindiran is called rarakitan.

The third type of sisindiran is paparikan. This sisindiran is called paparikan because it derives from the word parek which means close. The close here means that there is the closeness of pronunciation between cangkang and eusi such as in the following example:

Rincik-rincik hujan leutik,

paralak hujan tambaga.

Ngilik-ngilik ti leuleutik,

teu terang aya nu boga. ${ }^{7}$
Droplets of rain showers,

Come in the copper rain.

Paying attention to her since childhood

Turned out she already has someone

From the example of paparikan above, we can observe that the verse "rincik rincik hujan leutik" has a similar sound with the verse "Ngilik-ngilik ti leuleutik", and the word "tambaga" is similar in sound with " $n u$ boga". Because of this similarity, this sisindiran is called paparikan. Another characteristic of paparikan is that the number of syllables in a verse is eight.

Furthermore, Salmun (1968, p. 57) explains that there are three main themes of sisindiran which are silih asih (romance), piwuruk (advice), and sésébréd (satire). These three themes enrich sisindiran which is engraved in Sundanese culture, from daily conversations to literary works. In Ronggeng Gunung, the kawih pattern is also delivered in the form of sisindiran explained above, and the themes are not far from those three themes.

\footnotetext{
${ }^{5}$ This term is actually used specifically to call a pair of buffalos or "munding sarakit" in Sundanese. ${ }^{6}$ https://almushtafa.wordpress.com/2015/03/12/sisindiran-paparikan-rarakitan-jeung-wawangsalan/, retrieved on 25 October 2017

${ }^{7}$ http://www.basasunda.com/2016/09/contoh-sisindiran-paparikan-silih-asih.html, retrieved on 25 October 2017
} 
Based on an interview with Bi Raspi, there are 16 songs performed in Ronggeng Gunung namely: Lulugu, Golewang, Raja Pulang, Ondai, Kawungan Banter, Parut, Dengdet, Kawungan Kulon, Liring, Menangis, Urung urung, Tunggul Kawung, Mangonét, Cacar Wurung, Torondol, and Kidung. Lulugu is the opening song which is then is followed by Golewang. When the ronggeng sings Golewang, the male dancers one by one enters the performing arena to dance with the ronggeng, then they dance in uniform and doing round for approximately 12-15 minutes, after that they have a break, and then they dance again, and so on until the performance ends. There is no standard how long a Ronggeng Gunung performance should be. It can be 2 hours, 3 hours, or even 5 hours, depending on request. The length of the performance will affect to the length of the song.

\section{METHOD}

This study used structuralism as both theoretical approach and method to elaborate the Kawih. According to Tyson (2006, p. 221), structuralism approaches literature in three specific areas of literary studies: the classification of literary genres, the description of narrative operations, and the analysis of literary interpretation. In this paper, we elaborated those three specific areas directly through the wholeness perspective as comprehensive as possible. What we mean by wholeness perspective is that the discussion on the three areas is in one package; we discussed the genre and the sub-genre of Kawih, continued directly by discussing the narrative operations (structural construction), and finally we gave the meaning to the content of the narratives as part of literary interpretation of which the narratives told us the cultural values as part of the internalization process of the mythical values in daily life, especially those related to the romance of solace, propriety, modesty, decency, and the importance of solidarity in overcoming life and its problems.

\section{DISCUSSION}

After discussing literary genres in Kawih above, thus, we can go further to the discussion on the content of the Kawih narrative. Here, we categorized the content by providing the themes suitable with the content of the narratives as follow:

\section{Passionate Romance}

Romance is the most found theme in the kawih of Ronggeng Gunung. We can assume that this happens because the birth of Ronggeng Gunung tradition is accompanied by the myth of romance between Dewi Kembang Samboja and Raden Anggalarang. Their love journey turned out to be rough because Raden Anggalarang was then murdered by the Bajo (pirates). On her journey, Dewi Kembang Samboja finally succeeded in taking revenge toward the pirates. The theme of a passionate romance can be seen from the following lyrics:

Geura bobot sok geura ayun

Immediately think 
Geura timang tarajukeun

Mun bogoh sok geura lakon

Mun hayang sok buru lajukeun
Immediately consider

If it's love, you have to act fast

If you want, you have to immediately do it

The lyrics of the kawih above is a type of paparikan, which explains that if love has grown, then it should be immediately confessed to, so there will be no regret. If you have already considered the advantages and disadvantages and if you have already truly loved, then you should not delay, and you should immediately confess your love. Another topic of love with a different context is also narrated in another Ronggeng Gunung. This context of love is illustrated in the following humorous paparikan:

Kawung pugur gening mah sisi lembur

Ditinggur ku dadap ngora

bujang guyur gening sok salembur

Kaedanan ku randa ngora
Kawung pugur is on the end of the village Hit by a young dadap

There's a young man making an uproar the village

By being crazy of a young widow

This paparikan explains that there is a young man who truly loves a woman. However, the woman is a widow which in the end, the love craziness of this man makes the village in an uproar. It won't be a problem whether it's a maiden or a widow when love has come. This slightly different context is also explained in this paparikan.

The topics of love presented in the lyrics of Ronggeng Gunung are ordinary loves experienced by anyone. This is a pure and natural feeling possessed by everyone. The theme of love is indeed a universal and existed in every genre of literature. From the past until now, love is always the most discussed topic. Even popular songs, both modern and traditional, often talk about love in their lyrics. Ronggeng Gunung, which is often linked to the story of Dewi Kembang Samboja has predominantly love-themed lyrics. Therefore, the theme of love in Ronggeng Gunung appears to be a justification toward the myth of Dewi Kembang Samboja itself.

\section{The Romance of Solace}

Previously, love as the most delivered theme in both oral and written literary tradition is explained. However, there are also the theme of love that ends tragically as happens in William Shakespeare's Romeo and Juliet. Both lovers died while carrying their eternal love. The theme of love-induced sorrow is also present in the lyrics of Ronggeng Gunung. Moreover, the story of Dewi Kembang Samboja's love journey is similar to those of Romeo and juliet. Raden Anggalarang, the lover of Dewi Kembang Samboja died tragically by being beheaded by the pirates who attacked the kingdom. To preserve her love, Dewi Kembang Samboja then created the dance of Ronggeng Gunung.

The lyrics about the romance of solace can be observed from the following three lyrics. The first lyrics are the third type of sisindiran, namely paparikan.
Kadongdong mah amis caina
June plum has a sweet juice
Dipeureut mah dina jambangan
Squeezed out into a bowl 
Abongkena sok kanu hina

Saukur pake lantaran
Just because it's a lowlife

Only used as a tool

This paparikan explains a satire for upperclassmen who oppress and humiliate people whose status are below them. This paparikan narrates someone who's heartbroken after being used by the 'higher people', it's similar with the idiom "leaving after having fun". The narrator of the paparikan has expected so much, but the reality says otherwise, the upperclassman eventually leaves her easily. Another sorrow appears in the following paparikan:

Melak bawang dinu gawir

Dipacokan ku tikukur

Awak begang sok balas mikir

Kabogoh direbut batur
Planting an onion on a cliff

Pecked by a zebra bird

Thin body because of brooding over lover taken by another

The event happened in the above paparikan is possible to happen to anyone. How can the speaker not be heartbroken when the beloved lover is taken away by other people? Her heart is broken that her body becomes thin because of brooding over it. Heartbreaks indeed make people forget the reality, as if they forget that there are still many people out there who are possibly better. However, the memories of the lover must be hard to forget, moreover if he's taken away by other people. A different narration of the sorrow of love is present in this paparikan. The sorrow from a lover who breaks our heart can make us forget about our own self. We expect our lover to love and protect like how a lover is supposed to be, but it turns out that he breaks our heart instead.

\section{Unrequited Love}

Love stories do not always run smoothly. Someone can expect much to find love, but eventually the love can choose another person. This kind of love story becomes a theme of many songs, both the classic ones and modern ones. Not only in songs, this kind of story often appears in love-themed novels or films, such as in Marah Rusli's Siti Nurbaya, Achdiat Kartamihardja's Atheis, and F. Scott Fitzgerald's The Great Gatsby, and others. The novel Siti Nurbaya published in 1922, for instance, narrates the love story between Siti Nurbaya and Syamsul Bahri, although their love journey does not run smoothly. These lovers are faced with a hard obstacle which eventually leads to the end of their love. The story of unrequited love is present in the lyrics of Ronggeng Gunung, but of course using a different point of view. As in the following paparikan:

$\begin{array}{ll}\text { Lawon bodas sok sulam herang } & \text { White fabric embroidered translucent } \\ \text { Diwiru mah wiru sisina } & \text { The edge is sewn neatly } \\ \text { Mikawelas sok mikaheman } & \text { After loving wholeheartedly } \\ \text { Hanjakal teu katarima } & \text { Unfortunately it's unrequited }\end{array}$

The above lyrics illustrate someone who has attempted to love her darling, but it turns out that she does not reciprocate the love. This kind of story is similar to what happens in the novel The Great Gatsby by F. Scott Fitzgerald. The main character of the novel is Jay Gatsby who truly loves Daisy, but because of some reasons their love has to come to an 
end. Daisy married another man. After a few years, Gatsby crosses the path again with Daisy. Gatsby then attempts with all his might to get Daisy's love, but in the end it fails. His love is unrequited. A similar theme is also present in the following paparikan:

Pangandaran sok purbahayu

Jalana mah sok ka babakan

Panasaran sok hayang milu

Hanjakal mah teu diajakan
Pangandaran purbarahayu

Using the road to Babakan

Always curious, wanting to join

But unfortunately no one asks

From the above lyrics, it is narrated that someone is expecting to be asked to go together to a certain place, or to be asked to build a family together, however after waiting and expecting for a long time, the darling never asks, and even leaves.

On the other hand, the event of confessing unrequited love is also narrated in wawangsalan. As discussed above, wawangsalan has a double meaning; as a riddle and as a satirical expression.

\section{Moral Advice}

As explained by Salmun, that one of the themes contained in sisindiran is moral advices, which is a characteristic of the Sundanese who holds the principles of silih asah, silih asih and silih asuh. For instance, is in the following lyrics:

Melak taleus sok dinu hieum

Melak kacang sok na gagawir

Ari geus mah sok deudeuieun

Mun acan so panasaran
Planting taro on a shady place

Planting nuts on a cliff

If we already adore it, we want more,

If we haven't, we're curious

The above lyrics might possibly considered as a sisindiran especially paparikan, but structurally, the lyrics cannot be categorized as paparikan. This is probably a spontaneous style by Bi Raspi as a Ronggeng while singing these lyrics, which are usually adjusted with the context of place and audience who watch the Ronggeng Gunung performance. Regardless, the content and the lyrics are in the form of advice which explains about someone who is obviously always curious if she has not tried something she wants. The curiosity will turn into adoration if what she expects makes her happy, makes her deudeuieun, makes her keep wanting for more. Another instance of advice exists in the following lyrics:

Mun poek mah teu ngundang obor

Mun sieun mah ngajak batur

Mun bala dicacag heula
If it's dark and you don't bring a torch

If you're afraid, ask a friend

If it's lush, then chop it first

Structurally, the above lyrics cannot be categorized as sisindiran. However, the content and the lyrics are in the form of advice so mankind will always bring light when they are in darkness or life exhaustion. There must be guidance so living on earth will always be peaceful. If during the journey, there is still a feeling of inconvenient, then ask a friend to accompany, or in a broader context, ask a life partner to take the journey together so you will safely reach the destination and at the same time have a friend whom you can share 
anything. Moreover, if later there's an obstacle, then it has to be destroyed immediately so the journey will go on safely until reaching the destination. Another advice is expressed with a little humorous tone as in the following lyrics:

Mun hujan mah sok kundang payung If it rains, bring an umbrella

Mun leueur mah sok kundang iteuk If it's slippery, bring a cane

Mun labuh sok hudang sorangan If you fall, then wake up on your own

We are supposed to bring the appropriate tools based on the situation. If it is raining, then bring an umbrella. If there is flood, then bring a pair of boots, and bring a cane if the road is too slippery. However, immediately wake up when you fall, because independence in life is an important key to make people survive and succeed.

Iyus Rusliana (cited in Nalan, 1983, p. 10-11) argues that traditional arts have two main characteristics: the sacred and the profane. It is sacred as it is performed to something to be revered and supernatural. It is profane as it also serves to entertain the community. As something sacred, Ronggeng Gunung, in the beginning, is performed during traditional rites. They are, first, the calling for rain rite. The rite is started from bathing a cat in the well or on the river and followed by the performance of Ronggeng Gunung. Second, the plowing rite; the Ronggeng Gunung is performed before the rice fields are plowed. Third, it is for the rice planting; in this rite the dance is done throughout the whole process of planting. Fourth, it is for the harvest ritual; ronggeng is allowed to pick the first harvest which is kept as the next seeds. The complete performance is conducted throughout the whole harvest process. Fifth, it is for the rice transport that is from the field to the barns; Ronggeng Gunung is aiming at praising the abundant harvest. Sixth, it is for the birth ritual; the dance also aims to praise and send gratitude for the birth. Seventh, it is for the sea rite where the ronggeng is performed to pay homage for the sea gains. Eighth it is for the Muharam ritual. It is the new year of Islam.

As of today, Ronggeng Gunung functions mostly for the profanity. This shift also changes the image of ronggeng among the society. All ronggeng are thought to be easy-toget women for sum of money. However, it is contradicted by Nani, an activist and an artist of Ronggeng Gunung. She explains that whenever an audience gives some money, it is an appreciation and reward from the audience. The reward is given as the dancers have exerted all their best to dance and sing to entertain the audience and the money is given upon satisfactions. ${ }^{8}$

Although the tradition mainly played as entertainment, there are some great values maintained. These values are expressed in the lyrics, choreography, clothing, and performance arrangement. The values are closely related to the bigger local values in Southern Ciamis and Pangandaran. Besides, the tradition in those areas also functions to arrange and control the environment and helps the communities to understand, embody the environment wholly and comprehend the reality (Saini, 1990, p. 55). By probing the

\footnotetext{
${ }^{8}$ Ulfah Kurniawaty, Siti Nurbayani, \& Mirna Nur Alia A. “ Nilai Fungsional Struktural Kesenian Ronggeng gunung Dalam Kehidupan Masyarakat Banjarsari Kabupaten Ciamis”. sosiologi.upi.edu/unduhjournal.php?file=7_antologi_vol6...pdf
} 
values of the tradition, we can absorb the values and the character of the communities as part of the greater Sunda people. So, in short, understanding tradition means understanding the characters of Sunda people summarized in the phrase of "silih asah, silih asih, dan silih asuh"; caring each other, watching each other, and guiding each other (Sumardjo, 2006, p. 337). This principle is embodied in the Ronggeng Gunung in form of basajan (modesty), protecting ancestral heritage, and politeness. From this stance, then we go further to the last part of our discussion, that is, the literary interpretation or giving the concretization of the meaning of the Kawih in Ronggeng Gunung performance as people's internalization process of the mythical values into the cultural values in daily life.

\section{Modesty}

Literally, basajan means modesty. The modesty value is born in Ronggeng Gunung and presented by the waditra (musical instruments), the movement of the dance and the lyrics sung by the ronggeng. Ronggeng Gunung only uses three waditra: kenong (small gongs), kendang (drums), and goong (gong). Those three waditra are played simultaneously to produce musical harmony accompanying the dance and the singing of ronggeng.

The dance and instruments for the performance, according to $\mathrm{Ma} \mathrm{Ita}^{9}$, are similar to ketuk tilu dance. According to Atmadibrata (1990, p. 856), based on history, ketuk tilu had specific rules in its performance. They are the instruments or waditra, some female dancers or ronggeng, and waditra players, also known as panjak. Atmadibrata continues that the troupe made a performance at places that people can easily access. To invite the audience, the troupe members did the tatalu (playing wooden instruments), and played opening instrumentals. Whenever the enough audiences were gathered, it was opened with jajangkungan. At this act, ronggeng introduced herself by dancing and circling the oncor (oil lamp) installed at the center of the stage. After the jajangkungan, it is followed by wawayangan where ronggeng danced simultaneously while singing alternately. At this time the audience had a chance to dance with the ronggeng (Atmadibrata, 1990, p. 85). This is supported by Suharto (1999, p. 66-67) who suggests that Ronggeng Gunung precedes ketuk tilu. The pattern and the plot in ketuk tilu are similar to Ronggeng Gunung as well as Ronggeng Kaler performances which are initiated by playing the waditra and followed by the singing and dancing by the ronggeng. In Ronggeng Gunung, the male dancers enter the stage when the ronggeng sang golewang. In ketuk tilu the audience pick a ronggeng to dance with, while in Ronggeng Kaler a number of audiences can step into the stage and dance simultaneously without picking any specific ronggeng. In Ronggeng Gunung the male dancers are part of the group, not from the audiences. Hence there are similarities between the Ronggeng Gunung, Ronggeng Kaler and Ketuk Tilu.

On the other side, in terms of its functions, either Ronggeng Gunung or Ketuk Tilu serves similar aims. This is allegedly said that ketuk tilu in the beginning is part of the

\footnotetext{
${ }^{9}$ Interview on August 15, 2017
} 
sacred rite at the rice fields to welcome harvest season and pay homage toward Dewi Sri, the rice and fertility goddess. Both dances have departed from those aims.

Apart from this, there is a modesty value in the Ronggeng Gunung. The simplicity is with the number of the instruments: there are only three kinds of waditra. The value is shown in other traditions such as two instruments in the Cianjuran: kacapi and pipe. Even though there are only three instruments, they can produce harmonious music and they can put the audience under a spell. The audience found that the music is irresistible and they usually start to dance along. Other than simplicity with the instruments, the rhythm of the music is simple as well. According to the kendang player ${ }^{10}$, the pattern is different from other music. The drum pattern is simple and monotonous.

The next modesty lies in the dance itself. It is also monotonous and simple. The main pattern is to circle the ronggeng, like the earth circling the sun. The monotonous and repetitive move is, "lontang kiri, lontang kanan, lontang kiri, lontang kanan. Gerakan kakinya jungkit kiri, jungkit kanan, jungkit kiri, jungkit kanan" (throw left, throw right, throw left, and throw right. Tiptoe left, tiptoe right, tiptoe left, tiptoe right), until the song is over. Sinc it is a simple movement, anyone can do it with only one observation.

Another modesty value is on the clothing either worn by the female dancers (ronggeng) or the male ones. In the old times, the upper oufit was apok ${ }^{11}$ and the lower one was samping, the long piece of cloth whose ends being folded hence it looks like folded fan was dilamban. Nowadays, the apok is replaced by kebaya as many traditional Sundanese women wear. The men wear men's Sundanese traditional clothing: black pangsi, and a head band made of sarong.

The last one is on the lyrics. As it is been argued, the lyrics belong to the poetic genre called as sisindiran consisting of rarakitan, wawangsalan and paparikan. During the performance, the lyrics are mostly about amor, advices and satire using simple and daily language that common people can understand unlike the language used in poetry. Hence the interaction between the ronggeng and the audience goes naturally.

\section{Protecting Ancestral Heritage}

Other than modesty, which happens to the attitude of Sundanese community in general, other value reflected in Ronggeng Gunung is to protect the ancestral heritage. As having been discussed earlier, the myth behind the creation Ronggeng Gunung is the revenge against bajo (sea pirate) who killed Raden Anggalarang, who is Dewi Kamboja's beloved. In a Ronggeng Gunung performance, the ronggeng is at the center of th stage surrounded by male dancers. This act represents the myth. The central ronggeng is Dewi Samboja while the others are her followers who get ready to avenge her lover's death. The

\footnotetext{
${ }^{10}$ Interview is conducted on October 7, 2017

${ }^{11}$ Kemben is usually worn by women. This clothe only covers the chest to hip area, so the upper chest, shoulder are left uncovered. (Irawati Durban Ardjo, Perkembangan Tari Sunda: Melacak Jejak Tb. Oemay Martakusuma dan Rd. Tjetje Somantri. Sastrataya, Masyarakat Seni Pertunjukan Indonesia, Bandung:1998)
} 
male dancers wear sarong to deceive the pirates and while the villains are complacent, Dewi's disciples eliminate them with ease.

On the other hand, Suharto (1999, p. 11-52) argues that there is a relation between ronggeng and fertility rites to worship Dewi Sri. The same argument is proposed by Spiller (2010, p. 82) who opines that in Sundanese people, ronggeng is "perceived to be both divine (through their connection to the rice goddess) and profane (through their association with sexual behaviors that transgress conventional morality)." It serves double meanings: as a sacred personification of the rice goddess (Nyi Pohaci Sangiang Sri Dangdayang Trisnawati) and profane entertainment that depicts sexual desires.

Whenever the dance is performed during the planting or harvesting season, it might be categorized as part of the rituals to observe Dewi Sri, the fertility goddess. Hence, the ronggeng right in the middle of the circle is perhaps Dewi Sri who has to be protected so she will produce bountiful harvest in return. It might also be argued that those circling people are those who guard the heritage from external threats and demeaning, and at the same time they safeguard the people who own the tradition. The two very symbols, Dewi Samboja and Dewi Sri, represent things that need to be protected. Dewi Samboja is to be protected as she is the representation of Galuh Kingdom ${ }^{12}$, while Dewi Sri is the personification of rice, the main staple of Sundanese people. Now we can understand that this is the guarding tradition to preserve the Sundanese heritage. This has to be preserved by different generation because it's a Sundanese identity differentiating Sundanese culture from other cultures. It is part of Sundanese culture too as the Kawali inscription says Pakéna gawé rahayu pakeun heubeul jaya di buana, to accustom oneself with good deeds to gain the worldly successes.

\section{Politeness}

Another local wisdom that emanates from the dance is politeness. Whenever hearing the word ronggeng, people might think of negative things as people see a ronggeng as an easy-to-get woman. This is understandable as throughout history, ronggeng is identified as an entertaining lady. Spiller (2010, p. 82), in Erotic Triangles Sundanese Dance and Masculinity in West Java, tells that ronggeng is often treated as sexual objects, and it's not a rarity that she is also reputed as a prostitute. Ahmad Tohari's well-known novel, Ronggeng Dukuh Paruk, also depicts a ronggeng and sexuality. In his novel, a woman named Srintil should give in her virginity as the requirement for her to be a ronggeng. Being a ronggeng, Srintil soon became the prima donna among men. For her being a ronggeng was an honor even though she had to be a prostitute.

In West Java, other than the Ronggeng Gunung and Ronggeng Kaler, there are other folk tradition whose ronggeng is also taken a part: ketuk tilu, tayub, and tari keurseus. From those three traditions, it is tayub that is mostly identified as bringing negativity to the ronggeng. According to Atmadibrata (1990, p. 87), there are similarities between tayub and ketuk tilu

\footnotetext{
${ }^{12}$ See the explanation from the previous section
} 
dance, but tayub is performed mostly to the noblemen families of the West Java hence it is known as an elite culture. Just as the ketuk tilu, tayub is started with the tatalu or playing the wooden instruments or tools to announce and gather up the audience (mostly the elite group of the community). It is followed by some remarks from the host explaining the aims of the event. After that, comes the ngabaksan, it is a ritual to invite the guests to do the opening dance by giving the invited with a dancing scarf called soder. Tayub dance starts to gain momentum and the ronggeng come in and at this time alcoholic drinks are distributed. Under the influence of alcohol, some audiences get involved in the so called nyawer i.e. putting some money to the bra of the ronggeng. From this kind of context then ronggeng probably often gets sexual harassment, of which, in the later times considered as something usual, and this causes ronggeng gain their notoriety.

This image brings attentions to some people and they try to improve the reputation of the tradition. One of them is Aom Doyot (R. Ganda Kusumah), a nobleman from Sumedang who acted also as the Residence of Leuwiliang, Bogor at the beginning of the $20^{\text {th }}$ century (Caturwati, 2000, p. 19). He created a more decent and order tayuban; the audience danced alternately and not circling the ronggeng altogether; the alcohol was banned and the ronggeng did only dance. After this effort, there came new dance named as keurseus dance and tayub has changed into an orderly and polite performance. Since then, ronggeng kaler emerges. This dance has many similarities with tayub. In the performance that we observed in Caringin village, Banjarsari, Ciamis regency, the male dancers and the ronggeng dance in an orderly fashion and act politely. The sawer (giving money) is conducted by tying the money to the soder (the dancing scarf the ronggeng wear).

It is performed similarly in Ronggeng Gunung. When we watched Ronggeng Gunung, they dance it in similarly polite manner. There was not contact between male and female dancers. The music they dance was very simple and the male audience dancers never touched the ronggeng. Either ronggengs' or the audience's clothes were polite. The ronggeng wore kebaya which was not as open as the apok clothing, and the dance was orderly and polite, and there were not sensual stares either from the audience dancers or from the ronggeng.

In terms of the lyrics, Ronggeng Gunung uses polite and simple expressions which general audience can easily understand. As it has been shown before, the lyrics used by this performance are basically sisindiran (humorous satire of quip) whose words are polite. Even though it often says about romance, it is sacred in nature, and if there is a longing content, it is expressed in heightened and normal poems, like in the following:

Kembang wera sok daun turi

hayang leleuweunagn bae

lamun henteu mah era ku diri

hayang reureujengan bae.

It says that even though the speaker is under the amorous spell and wants to be alone with the lover, it also says about morality. This lyric teaches us to follow the religion and 
decency norms, and accordingly, love should obey these rules. From this instance, it can be concluded that Ronggeng Gunung implies politeness in its lyrics, cloths and dances.

\section{CONCLUSION}

As it has been discussed, we draw conclusions as follow. Ronggeng Gunung are from Southern Ciamis and Pangandaran from a series of myths dealing with the story of Dewi Siti Samboja (Dewi Rengganis) and her beloved Raden Anggalarang. However, these myths variously developed in different places and times. Initially, the whole process of the dance is sacred. For instance, the dancers should dip their heads under 7 different waterfalls. They have to have good command of the special spell called uluk-uluk. The musical instruments consist of kenong/ bonang (small gongs), one kendang (wooden drum) and one gong. Through time, there are some additional instruments such as kecapi (a kind of zither), rebab, and sambal. This dance was then more popularly called as Ronggeng Amen or Ronggeng Kaler.

The ronggeng, whichever the variation is, is folklore as it is collectively created by the society. As other folklores, the first creator is never known, neither the makers of the lyrics. Those ronggeng have truly existed in the community. They are humorous Sundanese quips consisted of wawangsalan, paparikan, and rarakitan. There are some lyrics that do not belong to sisindiran. Probably, it was spontaneously sung by the ronggeng during the performance. Upon analysis, the lyrics have different narrative contents. The narratives are strongly related to the general Sundanese song namely sisindiran which reflects numerous themes like passionate love, the romance of solace, advices, caring each other and so forth. From those three, the first one is the most commonly sung in the Ronggeng Gunung.

Every culture is produced by a society to present some values which is then taken as the identity of the society. And so is Ronggeng Gunung. Its values are part of the Southern Ciamis, Pangandaran, and its surrounding areas' identity. The values are upheld by the communities and by the Sundanese people in general. The values are modesty, decency and efforts to preserve ancestral heritage. Those three are integrated in Ronggeng Gunung, either in the dance patterns and styles, the lyrics and the clothing worn, and other parts of the tradition.

\section{REFERENCES}

Adams, H. (1976). Critical theory since Plato (Rev. ed.). New York: Harcourt Brace Jovanovich.

Ardjo, I. D. (1998). Perkembangan tari sunda: Melacak jejak tb. oemay martakusuma dan, rd. tjetje somantri. Bandung : Sastrataya, Masyarakat Seni Pertunjukan Indonesia.

Benson, P. (1993). Anthropology and literature. Chicago: University of Illinois Press.

Caturwati, E. (2000). R. tjetje somantri: Tokoh pembaharu tari sunda. Jogjakarta: Tarawang.

Cresswell, J. W. (2010). Research design: Pendekatan kualitatif, kuantitatif, dan mixed. Yogyakarta: Pustaka Pelajar. 
Danandjaja, J. (1984). Folklor indonesia: Ilmu gosip, dongeng, dan lain-lain. Jakarta: Grafiti Press.

Dhavamony, M. (1995). Fenomenologi agama. Yogyakarta: PT. Kanisius.

Endraswara, S. (2013). Metodologi penelitian antropologi sastra. Yogyakarta: Penerbit Ombak.

Erszberger, C., \& Kelle U. (2010). Menarik kesimpulan dalam metode campuran: Aturan integrasi. In Tashakkori, A. \& Teddies, C. (Ed.), Handbook of mixed methods in social \& behavioral research (pp. 410-437). Yogyakarta: Pustaka Pelajar.

Fetterman, D. M. (2008). Ethnography. In Given, L. M. (Ed.). (2008), The SAGE encyclopedia of qualitative research methods (pp. 288-292). California: SAGE Publication.

Fitzgerald, F. S. (1993). The great gatsby. Hertfordshire: Wordsworth Classic.

Geertz, C. (1973). The interpretation of cultures. New York: Basic Books, Inc.

Harsojo. (1988). Pengantar antropologi. Jakarta: Binacipta.

Haviland, W. A. (1984). Antropologi (1st ed.). Jakarta: Erlangga.

Horace. Art of poetry. In Adams, H. (Ed). (1991). Critical Theory Since Plato (Rev. ed.). New York: Harcourt Brace Jovanovich.

Keesing, R. (1992). Antropologi budaya: Suatu perspektif kontemporer. Jakarta: Erlangga. Kondisi dan masalah budaya sunda dewasa ini. (1990). Jakarta: Departemen Pendidikan dan Kebudayaan Indonesia.

Kuntjaraningrat. (Ed). (1999). Manusia dan kebudayaan di indonesia. Jakarta: Djambatan. Kuntjaraningrat, (1990). Pengantar ilmu antropologi. Jakarta: Rineka Cipta.

Kurniawaty, U., Nurbayani S., \& Alia, M. N. (2016). Nilai fungsional struktural kesenian ronggeng gunung dalam kehidupan masyarakat banjarsari kabupaten Cciamis. Undergraduate Thesis. Bandung: Universitas Pendidikan Indonesia.

Lechte, J. (2003). 50 filsuf kontemporer: Dari strukturalisme sampai posmodernitas. Yogyakarta: Kanisius.

Levi-Strauss, C. (1955). The structural study of myth. The Journal of American Folklore, 68, 428-444. Myth: A symposium (Oct-Dec 1955). Retrieved from www.jstor.org. Accessed in September 2017.

Mengenal taman wisata alam pananjung pangandaran. (2002). Ciamis: Perum Perhutani BKPH Pangandaran KPH Ciamis.

Nalan, A. S. \& Sarjono, A. R. (Eds). (1998). Catatan seni. Bandung: STSI Press.

Nalan, A. S. (Ed). (1999). Aspek manusia dalam seni pertunjukan. Bandung: STSI Press.

Palm, C.H.M. (1980). Sejarah antropologi budaya. Bandung: Jemmars.

Palmer, R. E. (2003). Hermeneutika: Teori baru mengenai interpretasi. Yogyakarta: Pustaka Pelajar.

Pals, D. L. (1996) Seven theories of religion: Dari animisme e.b. tylor, materialisme karl marx, hingga antropologi budaya clifford geertz. Yogyakarta: Qalam. 
Poyatos, F. (1988). Introduction: The genesis of literary anthropology. In Poyatos, F. (Ed.). (1988). Literary anthropology: A new interdisciplinary approach to people, signs, and literature. Amsterdam: John Benyamin Publishing Company.

Propp, V. (1997). Theory and history of folklore. Minneapolis: The University of Minnesota Press.

Putra, H. S. A. (2006). Strukturalisme levi-strauss: Mitos dan karya sastra. Yogyakarta: Galang Press.

Putra, H. S. A. (2003). Dari antropologi budaya ke sastra dan sebaliknya dalam sastra interdisipliner. Yogyakarta: Qalam.

Rusli, M. (1922). Siti nurbaya: Kasih tak sampai. Jakarta: Balai Pustaka.

Salmun, M.A. (1968). Kandaga: Kasusatran. Bandung: Gunaco.

Sedyawati, E. (1981). Pertumbuhan seni pertunjukan. Jakarta: Penerbit Sinar Harapan.

Soekanto, S. (1990). Sosiologi: Suatu pengantar. Jakarta: Rajawali Pers.

Spiller, H. (2010). Erotic triangles: Sundanese dance and masculinity in west java. Chicago: The University of Chicago Press.

Suhaety, E. (2012). Perubahan bentuk dan fungsi pertunjukan ronggeng gunung. Panggung, 22(4).

Suharto, B. (1999). Tayub: Pertunjukan dan ritus kesuburan. Bandung: Masyarakat Seni Pertunjukan Indonesia.

Sumardjo, J. (2006). Khazanah pantun sunda: sebuah interpretasi. Bandung: Kelir.

Suprayogo, I. \& Tobroni. (2001). Metodologi penelitian sosial-agama. Bandung: Remaja Rosdakarya.

Tashakkori, A. \& Teddie, C. (2010). Mixed methodology: Mengombinasikan pendekatan kualitatif dan kuantitattif. Yogyakarta: Pustaka Pelajar.

Taylor, R. (1981). Understanding the elements of literature. Oxford: Oxford University Press.

Thresnawaty, E. S. (2016, June 2). Raspi: Sang maestro ronggeng gunung. Patanjala, 8 (2), $235-250$.

Tohari, A. (1982). Ronggeng dukuh paruk. Jakarta: Gramedia Pustaka Utama.

Unsworth, J. (2005). New method in humanities research. Paper presented in The 2005 Lyman Award Lecture, 11, (2005, 11 November). National Humanities Center Research Triangle Park, NC. Retrieved from http://www3.isrl.uiuc.edu/unsworth/lyman.htm. Accessed on August 2009.

Van Peursen, C. A. (1988). Strategi kebudayaan. Yogyakarta: Kanisius. 
138 I Dian Nurrachman, Rohanda, Hasbi Assiddiqi, Deden Hidayat 